\title{
ASSESSMENT OF RESISTANCE OF HYBRIDS AND LINEAGES OF PASSION FRUIT TO BACTERIOSIS UNDER PROTECTED CULTIVATION
}

\author{
AVALIAÇÃO DE RESISTENNCIA DE HÍBRIDOS E LINHAGENS DE \\ MARACUJAZEIRO À BACTERIOSE, SOB CULTIVO PROTEGIDO
}

\begin{abstract}
Janlylle Ruama Yankovich ARRIFANO'; José Ricardo PEIXOTO²; Michelle Souza VILELA $^{3}$; Solange da Costa NOGUEIRA ${ }^{4}$; Thiago Campos de OLIVEIRA ${ }^{5}$; Daiane da Silva NÓBREGA

1. Graduada em Agronomia, Faculdade de Agronomia e Medicina Veterinária, Universidade de Brasília - UnB, Brasília, DF, Brasil. lylleyankovich@gmail.com; 2. Professor Titular, Faculdade de Agronomia e Medicina Veterinária - UnB, Brasília, DF, Brasil; 3. Professora Adjunta, Faculdade de Agronomia e Medicina Veterinária - UnB, Brasília, DF, Brasil; 4. Professora Adjunta, Faculdade de Agronomia e Medicina Veterinária - UnB, Brasília, DF, Brasil; 5. Mestre em Agronomia, Faculdade de Agronomia e Medicina Veterinária, Universidade de Brasília - UnB, Brasília, DF, Brasil. 6. Doutora em Agronomia, Faculdade de Agronomia e Medicina Veterinária, Universidade de Brasília - UnB, Brasília, DF, Brasil.
\end{abstract}

\begin{abstract}
Yield and longevity of yellow passion fruit have been reduced by diseases such as the bacterial spot caused by Xanthomonas axonopodis pv. passiflorae. Genetic resistance has been confirmed as the most efficient and economical correct option to minimize this disease problem. Aiming at it, the objective of this research was to evaluate the incidence, severity and progression of the disease in 12 genotypes of sour passion fruit, in seedling stage in nursery greenhouse after inoculation of Xanthomonas axonopodis pv. passiflorae. The inoculation was performed with an isolate collected in the Pipiripau Rural Nucleus, Brasilia-


with interval of 7 days except the first which was performed 11 days after inoculation. The incidence was estimated by the percentage of plants affected. To evaluate the severity, it was used the diagrammatic scale validated by Costa et al. (2018), with adaptations, using the measurement of the affected area by necrotic lesions on the leaf. All genotypes were susceptible to bacteriosis, 5 being considered moderately susceptible: $F_{1}$ BRS Pérola do Cerrado x Rosa Intenso, Mar20\#21, Mar20\#15b, Mar20\#24xMar20\#40 and FB200PL4R2 x Mar20\#2005, with a mean of severity ranging from 11 to $25 \%$ of injured area in leaves.
\end{abstract}

KEYWORDS: Bacterial spot. Xanthomonas axonopodis pv. passiflorae. Plant breeding. Passiflora edulis Sims. Genetic resistance. Seedlings.

\section{INTRODUCTION}

The yellow passion fruit has been grown throughout the country. Bahia, Ceará and Santa Catarina are the greatest states in the national production of the fruit. Brazil holds the first position in world production, with 554.59 tons produced in 2017 (IBGE, 2018). The Brazilian leadership in the world market has been repeated for two decades (MELETTI, 2011), and studies by Faleiro, Junqueira and Costa (2017), have shown that the country is responsible for the equivalent of $80 \%$ of world production.

In the first decade of the 2000 s there was a significant expansion in the cultivated area of passion fruit. Unfortunately, this fact has led to an increment in phytosanitary problems, reducing the time of economic exploitation of the crop, and becoming unfeasible to crop in certain regions (SANTOS FILHO et al., 2004). As a consequence, a retraction cycle of the cultivated area occurred, which has been occurring until the present day (MELETTI, BERNACCI; PASSOS, 2005).
Even with the great potential of passiculture in Brazil, there are some limitation factors that must be considered before glimpse its intensification, such as the lack of genotypes which confer high production (PIO VIANA; GONÇALVES, 2005), and resistance to several phytosanitary problems which affect the culture, such as bacteriosis, viruses, fungal diseases and nematodes (FREITAS et al., 2016).

The bacteriosis, which has the etiological agent Xanthomonas axonopodis pv. passiflorae, and fruit hardening virus caused by Cowpea aphidborne mosaic virus (CABM) have been identified as the major cause to harm producers. In the case of bacterial wilt, the loss may be total in the orchard (CARVALHO, STENZEL; AULER, 2015).

The genetic resistance is the most effective, economic and environmentally sustainable method to control Xanthomonas axonopodis pv. passiflorae (MELETTI, 2011), due to the high susceptibility to the disease present in commercial cultivars (VILELLA, 2012). 
A key aspect of genetic breeding for disease resistance is the quantification of disease or pathological symptoms, since broad and subjective classifications such as "low severity" are rarely useful. In this way, quantitative data are extremely useful to get a real rate of the damages and consequent losses of production due by the disease, facilitating the comparison among varieties in breeding programs and the efficiency of different control systems (LARANJEIRA, 2005). For this purpose, several devices have been proposed, such as diagrammatic scales for disease evaluation (BERGAMIN FILHO; AMORIM, 1996; COSTA et al., 2018). A scale to evaluate bacteriosis was recently proposed by Costa et al. (2018), where severity scores were validated for this disease.
Thus, this study aimed to evaluate the resistance reaction to 12 genotypes of Passiflora edulis Sims, under seedlings, under protected cultivation, using valid severity score scales.

\section{MATERIAL AND METHODS}

The present research was carried out in a greenhouse at the Experimental Station of Biology (EEB) which belong to the University of Brasília (UnB), in Brasília, DF, Brazil, located at an altitude of $1010 \mathrm{~m}$, points $15^{\circ} 44^{\prime} \mathrm{S}$ and $47^{\circ} 52^{\prime} \mathrm{W}$. The genotypes used were selected within the breeding program carried out by the University of Brasilia in partnership with Embrapa. The origin of the 12 genotypes used in the experiment is shown in Table 1 .

Table 1. Origin of passion fruit genotypes (Passiflora edulis Sims) evaluated for resistance to bacteriosis, under greenhouse, in Brasília, DF, Brazil.

\begin{tabular}{ll}
\hline GENOTYPES & ORIGIN \\
\hline $\mathrm{F}_{1}$ BRS Pérola do Cerrado x Rosa Intenso & $\begin{array}{l}\text { Interspecific hybrid from BRS Pérola do Cerrado (+) and } \\
\text { genotype from } 5 \text { cycles of recurrent selection }\left({ }^{\Uparrow}\right)\end{array}$ \\
Mar20\#21 & Genotype from 5 recurrent selection cycles \\
Rosa Intenso & Genotype from 5 recurrent selection cycles \\
Mar21\#100 x Mar20\#21 & $\begin{array}{l}\text { Intraspecific hybrid from two genotypes from } 5 \text { recurrent } \\
\text { selection cycles }\end{array}$ \\
AR2 & Genotype from 5 recurrent selection cycles \\
Mar20\#24P4 x ECL7P1 & Intraspecific hybrid from two genotypes from 5 recurrent \\
Mar20\#15a & selection cycles \\
Mar20\#15b & Genotype from 5 recurrent selection cycles \\
Mar20\#15c & Genotype from 5 recurrent selection cycles \\
Mar20\#24 x Mar20\#40 & Genotype from 5 recurrent selection cycles \\
& Intraspecific hybrid from two genotypes from 5 recurrent \\
Mar20\#21R4 & selection cycles \\
FB200PL4R2 x Mar20\#2005 & Genotype from 5 recurrent selection cycles \\
& Intraspecific hybrid from two genotypes from 5 recurrent \\
& selection cycles \\
\hline
\end{tabular}

The experiment started on $05 / 12 / 2018$, with sowing in polystyrene trays containing Vivatto Slim Plus ${ }^{\circledR}$, an artificial substrate from Technes Agrícola Ltda. On 06/12/2018, the seedlings were transplanted to $2 \mathrm{~L}$ plastic bags container filled with red-yellow latosol, which were watering daily, and received fertigation every two weeks in a concentration of $50 \mathrm{~g}$ of urea by $10 \mathrm{~L}$ of water.

The experimental design was a randomized block in split-plot arrangement: the plots were the genotypes, and the sub-plots were the four evaluation periods (number of days increasing from the date of inoculation).

The isolates of Xanthomonas axonopodis pv. passiflorae (UnB-1397), were collected at Pipiripau's Rural Nucleus on November 13, 2018.
The treatment to obtain isolates was carried out at the Laboratory of Bacteriology at the Department of Plant Pathology at UnB. To obtain pure cultures, the isolates were subcultured in growth medium 523 (KADO; HESKETT, 1970) which provides fast growth and transparency (ROMEIRO, 2001) by the streak plate method. After colony growth, which were incubated in an oven at $30^{\circ} \mathrm{C}$ for $72 \mathrm{~h}$, the suspension of bacteria was prepared at a concentration of $1 \times 10^{6} \mathrm{CFU} / \mathrm{mL}$, adjusted turbidimetrically using a spectrophotometer. The wavelength used was $550 \mathrm{~nm}$, reaching an absorbance of 0.323 , predetermined by means of a calibration curve, to result in a concentration of $1 \times 10^{6} \mathrm{CFU} / \mathrm{mL}$. 
On October 26, 2018, the inoculation began. As tools to help along the pathogen penetration were used scraper brushes bearing steel bristles. The area comprised by each brush is approximately $72 \mathrm{~cm}^{2}$. The purpose was to cause injuries in the leaf blade surface of the plants. The injury was performed in 2 leaves per plant, which are the penultimate pair of leaves. The bacterial suspension was sprayed in sequence. The plants were kept in a humid chamber for $72 \mathrm{~h}$ and were covered with a previously humidified canvas structure. This period of inoculation corresponded to the beginning of the rainy season.

Four evaluations were carried out during November. The first one was performed 11 days after inoculation and the others in an interval time of
7 days between one and other after the first. During the four evaluations, the incidence and severity rate were measured. For this, the diagrammatic scale validated by Costa et al. (2018) with adaptation, which uses the measurement of the necrotic lesions in the leaf area to assign grades varying on a scale of 0 to 5 . The grades were assigned according to the following classification: 0 - leaf with no symptoms; $1-1$ to $10 \%$ of total leaf area with necrotic lesions; 2 - 11 to $25 \%$ of total leaf area with necrotic lesions; 3 - 26 to $50 \%$ of total leaf area with necrotic lesions; 4 - more than $50 \%$ of the total leaf area with necrotic and 5 - leaf abscission (Figure 1). The incidence was later estimated by the percentage of plants that presented severity $\geq 1$.
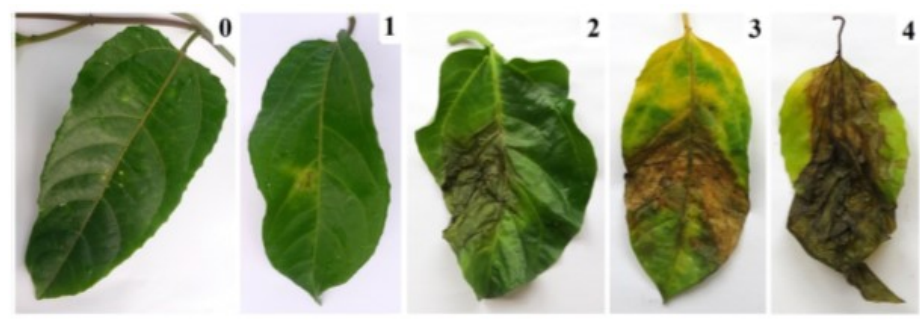

Figure 1. Scale of notes for the evaluation of bacteriosis severity of sour passion fruit (Passiflora edulis Sims) inoculated with (Xanthomonas axonopodis pv. passiflorae).

Source: Costa (2018)

In the original diagrammatic scale validated by Costa et al. (2018), grades ranging from 0 to 5 were used, however, in the present work note 6 was attributed to plants that died as a result of the pathogen attack.

From the severity averages obtained, genotypes were classified for resistance or susceptibility, from the following scale: (0) Resistant; ( $\geq 1)$ Moderately resistant; ( $\geq 2)$ Moderately susceptible; $(\geq 3)$ Susceptible; $(\geq 4)$ Very susceptible (adapted from VIANA et al., 2014).

The studies performed by Campbell and Madden (1990), and the equation proposed by them, were used to calculate the area under the disease progress curve (AUDPC).

The original data were submitted to variance analysis $(\mathrm{P} \leq 0.005)$ and the means were grouped in the Scott-Knott test. All analyzes were ran using the software Sisvar (FERREIRA, 2014).

\section{RESULTS AND DISCUSSIONS}

\section{Incidence of Xanthomonas axonopodis pv. passiflorae}

The mean incidence rates of Xanthomonas axonopodis pv. passiflorae, in the four evaluation periods, can be observed in Table 2.

Table 2. Incidence and resistance reaction (R) to bacteriosis (Xanthomonas axonopodis pv. passiflorae) in passion fruit (Passiflora edulis Sims).

\begin{tabular}{lllll}
\hline \multirow{2}{*}{ GENOTYPE } & \multicolumn{4}{l}{ INCIDENCE } \\
\cline { 2 - 5 } & E1 & E2 & E3 & E4 \\
\hline F1 BRS Pérola do Cerrado x Rosa Intenso & $11.11 \mathrm{aA}$ & $16.66 \mathrm{aA}$ & $49.99 \mathrm{bA}$ & $61.11 \mathrm{bA}$ \\
Mar20\#21 & $16.66 \mathrm{aA}$ & $44.44 \mathrm{bA}$ & $61.11 \mathrm{bA}$ & $61.11 \mathrm{bA}$ \\
Rosa Intenso & $16.66 \mathrm{aA}$ & $72.22 \mathrm{bB}$ & $72.22 \mathrm{bA}$ & $83.33 \mathrm{bA}$ \\
Mar 21\#100 x Mar 20\#21 & $16.66 \mathrm{aA}$ & $94.44 \mathrm{bB}$ & $88.88 \mathrm{bA}$ & $88.88 \mathrm{bA}$ \\
AR2 & $0.00 \mathrm{aA}$ & $72.22 \mathrm{bB}$ & $83.33 \mathrm{bA}$ & $77.77 \mathrm{bA}$ \\
Mar20\#24P4 x ECL7P1 & $38.88 \mathrm{aA}$ & $94.44 \mathrm{bB}$ & $100.00 \mathrm{bA}$ & $100.00 \mathrm{bA}$ \\
Mar20\#15a & $0.00 \mathrm{aA}$ & $66.66 \mathrm{bB}$ & $72.22 \mathrm{bA}$ & $83.33 \mathrm{bA}$
\end{tabular}




\begin{tabular}{lllll} 
Mar20\#15b & $0.00 \mathrm{aA}$ & $88.88 \mathrm{bB}$ & $72.22 \mathrm{bA}$ & $94.44 \mathrm{bA}$ \\
Mar20\#15c & $0.00 \mathrm{aA}$ & $88.88 \mathrm{bB}$ & $94.44 \mathrm{bA}$ & $94.44 \mathrm{bA}$ \\
Mar20\#24 x Mar20\#40 & $0.00 \mathrm{aA}$ & $77.77 \mathrm{bB}$ & $83.33 \mathrm{bA}$ & $94.44 \mathrm{bA}$ \\
Mar20\#21R4 & $16.66 \mathrm{aA}$ & $83.33 \mathrm{bB}$ & $88.88 \mathrm{bA}$ & $88.88 \mathrm{bA}$ \\
FB200PL4R2 x Mar20\#2005 & $0.00 \mathrm{aA}$ & $77.77 \mathrm{bB}$ & $83.33 \mathrm{bA}$ & $83.33 \mathrm{bA}$ \\
\hline
\end{tabular}

Brasília, DF, Brazil, 2018.

$\mathrm{E}=$ evaluation time; $\mathrm{SD}=$ mean incidence (4 evaluations). Different lowercase letters on the same line and different capital letters in the same column indicate significant differences (Scott-Knott, $\mathrm{P} \leq 0.05$ ).

In relation to the incidence of Xanthomonas axonopodis pv. passiflorae, it was not shown statistical significance differences between the genotypes. However, in the first evaluation, performed 11 days after inoculation, a numerical significance difference was observed. The genotype Mar20\#24P4 $x$ ECL7P1 showed the highest percentage of plants with symptoms $(38.88 \%)$ expressing greater susceptibility than the double of the Mar20\#21, Rosa Intenso, Mar 21\#100 X Mar $20 \# 21$ and Mar20\#21R4, which resembled a percentage of number of plants that presented symptoms $(16.66 \%)$. The third genotype with the highest incidence was the control BRS Pérola do Cerrado x Rosa Intenso (11.11\%). The others had no symptoms.

In the second evaluation, performed 18 days after inoculation, significant statistical differences were observed between the control genotype F1 BRS Pérola do Cerrado x Rosa Intenso (16.66\%) and Mar20\#21 (44.44\%) in relation to the other 10 2). These 2 materials showed superior resistance in the incidence parameter, in this time interval compared to the others. The genotypes Mar20\#24P4 x ECL7P1 (94.44\%) and Mar21\#100 x Mar20\#21 (94.44\%) showed the highest percentage of plants with symptoms. Then, genotypes Mar20\#15b and Mar20 \# 15c behaved similarly (both with $88.88 \%$ of symptomatic plants). These last two genotypes had shown no symptoms in the first evaluation. This reaction demonstrates fast manifestation of the disease, in the critical period, 12 to 18 days after inoculation. Among the genotypes that showed variations $(\mathrm{P} \leq 0.05)$ with higher incidence, Mar20\#15a showed the lowest number of plants with disease incidence $(66.66 \%)$ for this interval of time.

In evaluations number 3 and 4 , carried out after 25 and 32 days after inoculation, there were no statistically significant differences among any of the genotypes. However, in the third evaluation, Mar20\#24P4 x ECL7P1 presented $100 \%$ of plants with symptoms, and Mar20\#15c presented $94.44 \%$, followed by Mar 21\#100 x Mar20\#21 and Mar20\#21R4. In the fourth evaluation the genotype Mar20\#24P4 x ECL7P1 was the only one to present all plants with symptoms, followed by genotypes Mar20 \# 15b and Mar20\#15c, both with $94.44 \%$ of incidence. Although they did not have statistically significant differences, F1 BRS Pérola do Cerrado $\mathrm{x}$ Rosa Intenso and Mar20\#21R4 genotypes were superior, with only $61.11 \%$ of disease incidence (Table 2).

Variations $(\mathrm{P} \leq 0.05)$ were found in 11 of the 12 genotypes, between the first and second evaluation. Only F1 BRS Pérola do Cerrado x Rosa Intenso behaved differently, differing statistically only between the second and third evaluation.

Costa (2018), conducted 3 experiments in a such similar way to the methodology used in this study, evaluating the incidence, severity and other variables of anthracnose, scab, septoriosis, and bacteriosis in passion fruit, at different times, leading the culture under protected cultivation and performing the inoculation at the seedling stage. Similar to the results presented here, there was no difference among genotypes for the mean for bacteriosis incidence in the experiment 1 . In the experiment 2, also there was no variation, but MAR20\#10 presented $22.2 \%$ less disease symptoms when compared to MAR20\#2005, which showed the highest incidence. In the experiment 3, the genotypes also did not vary in the incidence, and all plants presented the highest percentage of incidence in the evaluation 2, except MAR20\#24 that reached $100.0 \%$ of incidence in the evaluation 4 . The experiments with higher levels of incidence corresponded to the rainy season which was when the isolates were inoculated.

Differently, Miranda (2018), who conducted the open field experiment and evaluated the resistance of 31 passion fruit genotypes to 4 diseases, at 5 different times, found different significances for incidence and severity mean caused by bacteriosis. The lowest averages were found in genotypes AP1 P3 x ECRAM R3 (1.35) and MAR 20\#24 P4 R4 x ECL7 P1 R4 (1.41), and the highest averages were the genotypes AR2 R4, RUBI GIG R4 and MAR 20\#21 R4. Even so, all plants were affected by the disease.

Other works have also found numerical variations, just like this, for the parameter in 
question. Some verified relevant resistance to the disease, such as the one conducted by Nogueira (2016), under greenhouse conditions. After 6 evaluation periods, only the cultivar 'BRS Gigante Amarelo' differed from the other 9 progenies of passion fruit evaluated in relation to the incidence, obtaining a result of $85.74 \%$ of plants affected. Miranda (2018), in field, also obtained incidence data that indicated a medium range of resistance of the cultivar 'BRS Gigante Amarelo'.

Viana et al. (2003) also evaluated the resistance of several progenies to the isolates of Xanthomonas axonopodis pv. passiflorae in a greenhouse, with regard to incidence analysis, and classified the MSCA material as disease resistant. The Giant Yellow, ECL-7 and EC3-0 progenies as moderately resistant. These results differ from those found by Nogueira (2016), who classified MSCA as susceptible. There are also divergences in the study of Costa et al. (2018) who classified EC3-O as susceptible to the disease and Fuhrmann et al. (2014), which classified the cultivar 'BRS Gigante Amarelo' as the most susceptible genotype among others 35 .
Even though none of these discrepant genotypes were used in the present work. It is important to mention the disharmony already observed in the literature to demonstrate the ability of some elements to influence the results as such as: climatic variability, pathogen virulence, and experimental model data used, such as the number of plants evaluated and the number of evaluations done (GONÇALVES, 2000). Besides these factors, Costa et al. (2018) also describes others, such as: different inoculation methods and inoculum concentrations used; conditions of plant growth, as available space for root development; age of the plant at the time of inoculation, nutritional conditions, among others.

\section{Severity of Xanthomonas axonopodis pv. passiflorae}

The mean severity of Xanthomonas axonopodis pv. passiflorae in the four evaluation periods, can be checked in Table 3, which shows variations among the genotypes $(\mathrm{P} \leq 0.05)$.

Table 3. Severity and resistance reaction (R) to bacteriosis (Xanthomonas axonopodis pv. passiflorae) in passion fruit (Passiflora edulis Sims).

\begin{tabular}{lllllll}
\hline \multirow{2}{*}{ GENÓTIPOS } & \multicolumn{2}{l}{ SEVERIDADE } & \multicolumn{2}{l}{ S } & \multirow{2}{*}{ R } \\
\cline { 2 - 5 } & E1 & E2 & E3 & E4 & & \\
\hline F1 BRS Pérola do Cerrado x Rosa Intenso & $0.89 \mathrm{Aa}$ & $2.22 \mathrm{bA}$ & $2.72 \mathrm{bA}$ & $3.80 \mathrm{cA}$ & $2.41 \mathrm{a}$ & $\mathrm{MS}$ \\
Mar20\#21 & $1.06 \mathrm{Aa}$ & $2.80 \mathrm{bA}$ & $3.31 \mathrm{bA}$ & $3.04 \mathrm{bA}$ & $2.55 \mathrm{a}$ & $\mathrm{MS}$ \\
Rosa Intenso & $1.21 \mathrm{Aa}$ & $2.87 \mathrm{bA}$ & $4.06 \mathrm{cB}$ & $4.33 \mathrm{cA}$ & $3.12 \mathrm{~b}$ & $\mathrm{~S}$ \\
Mar21\#100 x Mar 20\#21 & $1.42 \mathrm{Aa}$ & $2.91 \mathrm{bA}$ & $4.46 \mathrm{cB}$ & $4.51 \mathrm{cA}$ & $3.32 \mathrm{~b}$ & $\mathrm{~S}$ \\
AR2 & $1.25 \mathrm{Aa}$ & $4.35 \mathrm{bA}$ & $5.00 \mathrm{bB}$ & $5.00 \mathrm{bA}$ & $3.90 \mathrm{~b}$ & $\mathrm{~S}$ \\
Mar20\#24P4 x ECL7P1 & $1.55 \mathrm{Aa}$ & $3.22 \mathrm{bA}$ & $4.44 \mathrm{cB}$ & $5.00 \mathrm{cA}$ & $3.55 \mathrm{~b}$ & $\mathrm{~S}$ \\
Mar20\#15 & $1.88 \mathrm{Aa}$ & $2.50 \mathrm{aA}$ & $4.40 \mathrm{bB}$ & $4.33 \mathrm{bA}$ & $3.28 \mathrm{~b}$ & $\mathrm{~S}$ \\
Mar20\#15b & $1.22 \mathrm{Aa}$ & $2.94 \mathrm{bA}$ & $2.99 \mathrm{bA}$ & $3.55 \mathrm{bA}$ & $2.68 \mathrm{a}$ & $\mathrm{MS}$ \\
Mar20\#15c & $0.88 \mathrm{Aa}$ & $3.38 \mathrm{bA}$ & $4.33 \mathrm{bB}$ & $4.27 \mathrm{bA}$ & $3.22 \mathrm{~b}$ & $\mathrm{~S}$ \\
Mar20\#24 x Mar20\#40 & $1.02 \mathrm{Aa}$ & $2.94 \mathrm{bA}$ & $3.75 \mathrm{bA}$ & $4.13 \mathrm{bA}$ & $2.96 \mathrm{a}$ & MS \\
Mar20\#21R4 & $1.33 \mathrm{Aa}$ & $3.33 \mathrm{bA}$ & $4.05 \mathrm{bB}$ & $4.33 \mathrm{bA}$ & $3.26 \mathrm{~b}$ & $\mathrm{~S}$ \\
FB200PL4R2 x Mar20\#2005 & $0.94 \mathrm{Aa}$ & $2.99 \mathrm{bA}$ & $3.66 \mathrm{bA}$ & $3.88 \mathrm{bA}$ & $2.87 \mathrm{a}$ & $\mathrm{MS}$ \\
\hline
\end{tabular}

Brasília, DF, Brazil, 2018.

$\mathrm{E}=$ evaluation time; $\overline{\mathrm{S}}=$ average severity (4 evaluations). $\mathrm{R}$ = Classification of resistance (adapted from VIANA et al., 2014): (0) Resistant; $(\geq 1)$ Moderately Resistant; $(\geq 2)$ Moderately susceptible; $(\geq 3)$ Susceptible; $(\geq 4)$ Highly susceptible. Different lowercase letters on the same line and different capital letters in the same column indicate significant differences (Scott-Knott, $\mathrm{P} \leq 0.05$ ).

Regarding the first evaluation, it was observed that there were no statistically significant differences between averages of severity among the genotypes, although there was a numerical variation, which the genotype Mar20 \# 15a was the one that obtained the highest percentage of area or foliar tissue affected by the disease (1.88) in the first evaluation, 11 days after inoculation. Next, the genotypes Mar20\#24P4 x ECL7P1 (1.55) and Mar
21\#100 x Mar 20\#21 (1.42) were included. The genotype that presented the lowest percentage of leaf area or injured tissues with symptoms was Mar20\#15c (0.88).

Likewise, in the second evaluation, occurring 18 days after inoculation, there were no significant differences in the severity mean among the twelve genotypes. 
In the third evaluation it was noticed that there was significant difference in 7 genotypes, out of 12 evaluated. The AR2 genotype was highly susceptible (5.0), since it already presented leaf abscission in all plants evaluated in the penultimate evaluation. The genotypes Rosa Intenso, Mar 21\#100 X Mar 20\#21, AR2, Mar20\#24P4 x ECL7P1, Mar20\#15a, Mar20\#15c and Mar20\#21R4 presented at least $50 \%$ of the leaf area or tissue already with necrotic lesions. Mar20\#21, Mar20\#24 $x$ Mar20\#40 and FB200PL4R2 x Mar20\#2005 presented 26 to $50 \%$ of the total leaf area with necrotic lesions. Therefore, Mar20\#15b (2.99) and F1 BRS Pérola do Cerrado x Rosa Intenso (2.72) presented the lowest proportion of injured area - 11 to $25 \%$.

In the fourth evaluation, there was no statistically significant difference among any of the genotypes, even though Mar20\#24P4 x ECL7P1 was also reaching the level of abscission of inoculated leaf in all plants (5.0), just as AR2 had reached the third evaluation. The genotypes Rosa Intenso, Mar 21\#100 x Mar 20\#21, Mar20\#15a, Mar20\#15c, Mar20\#24 x Mar20\#40 and Mar20\#21R4 suffered necrotic lesions in more than $50 \%$ of the leaf area, showing susceptibility. The genotypes F1 BRS Pérola do Cerrado x Rosa Intenso (3.80), Mar20\#21 (3.04), Mar20\#15b (3.55) and FB200PL4R2 x Mar20\#2005 (3.88) showed moderate susceptibility. All of them were with 26 to $50 \%$ of the total leaf area with lesions. Although no statistically significant difference was observed in relation to the numerical difference, the genotype Mar20\#21 presented the smallest proportion of area with lesion at 32 days after inoculation.

Regarding disease progression according to the evaluation period, all genotypes presented statistically significant differences among the severities observed between the first and second evaluation periods. Three genotypes showed statistical differences significant in the severities mean observed between the second and third evaluation: Rosa Intenso, Mar 21\#100 x Mar20\#21 and Mar20\#24P4 x ECL7P1. The control genotype F1 BRS Pérola do Cerrado x Rosa Intenso presented statistically significant differences among the means of severity observed between the third and fourth evaluation.

From the severity averages observed over time, it was possible to classify the genotypes for the resistance range, according to the methodology proposed by Viana et al. (2014). Although Mar20\#24 x Mar20\#40 also obtained a necrotic lesion greater than $50 \%$ of its leaf area in the fourth evaluation, its mean among the evaluations (2.96), classifies it as moderately susceptible. The four genotypes were also classified as moderately susceptible: the control genotype F1 BRS Pérola do Cerrado x Rosa Intenso (2.41), Mar20\#21 (2.55), Mar20\#15b (2.68), and FB200PL4R2 x Mar20\#2005 (2.87). All genotypes classified as moderately susceptible had the severity mean ranging from 11 to $25 \%$ of leaf area or tissues with lesion. All other genotypes were classified as susceptible, as they obtained severity higher than 3, inasmuch as, the severity mean throughout the evaluations was between 26 and 50\% of injured areas.

Although they did not have statistically significant differences, F1 BRS Pérola do Cerrado $\mathrm{x}$ Rosa Intenso, Mar20\#21 and Mar20\#15b were superior, with the lowest percentage of lesions in their foliar tissues, which occurred 32 days after inoculation.

The results obtained are similar to those obtained by Miranda (2018), regarding the variation $(\mathrm{P}<0.005)$ among the evaluation periods for the severity of the disease. However, the mentioned experiment found medium resistance in the materials AP1 P3 x ECRAM R3, MAR 20\#24 P4 R4 x ECL7 P1 R4 and Rosa INT P1 R1, with averages of $1.353500,1.410000$ and 1.421500 , respectively, much lower than those obtained in this work. It is important, to mention the superiority of the materials used in his experiment: hybrids from crosses between resistant and more productive plants of previous cycles in the program of improvement of passion fruit in development at Fazenda Água Limpa as pointed out by the author. In that period, there were already showing lower incidence and severity mean when compared to the other genotypes, and emphasizing the importance of hybridization between materials with desirable agronomic characteristics and levels of resistance to the main diseases. The author also emphasizes the importance of sharing hybridization technology to fruit producers, as well as already mentioned by Faleiro et al. (2013) knowing the great challenge that bacteriose represents to the greater productivities of Brazilian orchards.

In the experiment 1 of Costa et al. (2018), no materials resistant to bacteriosis were found, unlike experiment 2, in which MAR20\#10 and MAR20\#41 stood out with the highest number of resistant plants at the end of the study $(37.5 \%$ and $25 \%$, respectively). In addition to these two materials, all genotypes used in Experiment 2 of the study showed resistant plants. It should be noted that, as seen in the incidence parameter, this experiment corresponded to the dry season. In 
experiment 3, conducted in the rainy season, all genotypes used were denominated susceptible, having reached scores higher than 3.0. However, MAR20\#2005 and BRS GAI stood out for their numerical averages, respectively, $10.3 \%$ and $7.7 \%$ lower than YM FB200, which was considered the most susceptible.

Junqueira et al. (2003) mentioned the low variation among cultivars, while among plants, there was high variation. So many discrepancies show how important it is to carry out evaluations over time, for better confidence about the resistance of the materials used in the experiments, because as already mentioned by Laranjeira (2005), punctual studies are of little consequence for the resolution of the present challenges to the passion fruit diseases research. That is why advanced breeding programs are important.

\section{Area under the disease progress curve, caused by por Xanthomonas axonopodis pv. passiflorae}

The averages of the area under the disease progress curve, in the four evaluation periods, can be checked in Table 4, and are not expressed in any unit of measurement.

According to this analysis, there was no statistically significant difference between the genotypes $(\mathrm{P}>0.05)$, but the numerical difference among the genotypes that obtained the lowest and the highest values, respectively, F1 BRS Pérola do Cerrado x Rosa Intenso (51, 09) and AR2 (87.32) was $71 \%$. The genotypes with the smallest area are those that can be considered the most tolerant to bacteriosis, and the ones with the largest area are those that have progressed the most.

The averages found in the present study differ greatly from those found by Nogueira (2016).
The work conducted by Nogueira shows averages of ABDPC higher than those found in the present study, varying from 220.87 to 273.25 . The progeny that hosted the highest levels of disease were "Ruby Giant", and the progeny considered to be the most tolerant was "Rosa Intenso", and in the comparison of means by the Tukey test, there was also no significant difference among the progenies at the level of $5 \%$, but as in the present study, the numerical difference was higher $(23.71 \%)$.

Miranda (2004) conducted 2 experimental experiments in a greenhouse in an experimental area belonging to ESALQ-USP, in the city of Piracicaba (SP), at different periods time (September to December 2002 and January to March 2003). Inoculating Xanthomonas axonopodis pv. passiflorae isolates in 50-day-old plants, in 8 commercial cultivars of passion fruit and 2 wild populations. The incidence and severity evaluations were performed 7,14 and 21 days after inoculation. In the severity data, as in the present study, ABDPC results were obtained. In its first experiment, "Sul Brasil" was the genotype that obtained the lowest ABDPC, with a mean of 300.07, showing highest tolerance, and "MSBA" was the genotype with the highest ABDPC, with a mean of 436.47, showing a greater susceptibility. In the second trial, there was also no significant statistical difference among the materials, but obtained higher ABDPC mean than in the first experiment. The author reported that this is probably due to the highest UR present in the air in the period of January-March in SP. "Sul Brasil" remained the most tolerant genotype, with a mean of 386.87, and "Flora" behaved as the least tolerant genotype, with a mean of 547.36.

Table 4. The area under the disease progress curve (AUDPC).

\begin{tabular}{ll}
\hline GENOTYPE & AUDPC \\
\hline F1 BRS Pérola do Cerrado x Rosa Intenso & $51.09 \mathrm{a}$ \\
Mar20\#21 & $57.16 \mathrm{a}$ \\
Rosa Intenso & $68.01 \mathrm{a}$ \\
Mar 21\#100 x Mar 20\#21 & $72.41 \mathrm{a}$ \\
AR2 & $87.32 \mathrm{a}$ \\
Mar20\#24P4 x ECL7P1 & $76.59 \mathrm{a}$ \\
Mar20\#15a & $70.07 \mathrm{a}$ \\
Mar20\#15b & $58.32 \mathrm{a}$ \\
Mar20\#15c & $72.13 \mathrm{a}$ \\
Mar20\#24 x Mar20\#40 & $64.94 \mathrm{a}$ \\
Mar20\#21R4 & $71.55 \mathrm{a}$ \\
FB200PL4R2 x Mar20\#2005 & $63.57 \mathrm{a}$ \\
\hline
\end{tabular}

Brasília, DF, Brazil, 2018.

Different lowercase letters in the same column indicate significant differences (Scott-Knott, $\mathrm{P} \leq 0.05$ ). 
It is important to emphasize that the present study is in line with other studies carried out in the rainy season, resulting in a high epidemiological level. Despite the low variability presented by sour passion fruit for resistance to main diseases, any difference among materials or even within same genotype could mean valuable result data for genetic breeding and selection processes, which should be analyzed and compared.

As the price paid by the consumer in the domestic and foreign market continues to increase over time, once the fruit is retracted, the appreciation and demand for passionflower breeding programs should continue to increase and become more important every day, in a way to fulfill the objective of continuing to encourage producers to remain, or to join the pasiculture, even that the difficulties to crop are so discouraging.

\section{CONCLUSIONS}

Five genotypes were classified as moderately susceptible: F1 BRS Pérola do Cerrado $x$ Rosa Intenso, Mar20\#21, Mar20\#15b, FB200PL4R2 x Mar20\#2005 and Mar20\#24 x Mar20\#40 ordered in an increasing manner. The other 7 genotypes were classified as susceptible.

The genotypes F1 BRS Pérola do Cerrado $\mathrm{x}$ Rosa Intenso and Mar20\#21 presented the lowest values of plants with lesions: both with $61.11 \%$. The genotype Mar20\#24P4 x ECL7P1 obtained 100\% of plants with symptoms, showing to be totally susceptible to bacteriosis.

Future studies include tests with other pathogens and isolates, as well as field trials for genotype selection, in order to provide subsidies for the continuity of the breeding program.

The most promising genetic materials were selected for further field and greenhouse evaluations and new cycles of selection, self-fertilization and controlled crosses.

RESUMO: A produtividade e a longevidade dos pomares de maracujazeiro-azedo têm sido comprometidas em razão de doenças como a bacteriose, causada por Xanthomonas axonopodis pv. passiflorae. A resistência genética tem se confirmado como a opção mais eficiente e econômica para minimizar tal problema. Dessa forma, o objetivo deste trabalho foi avaliar a reação de 12 genótipos de maracujazeiro, em fase de mudas, sob cultivo protegido, à Xanthomonas axonopodis pv. passiflorae. A inoculação com isolado denominado UnB-1397 (1×10 CFU/mL), coletado no Núcleo Rural de Pipiripau, Brasília-DF, se deu pela indução de ferimentos. Foram realizadas 4 avaliações, com intervalo de 7 dias, sendo a primeira avaliação realizada 11 dias após a inoculação. A incidência foi estimada pela porcentagem de plantas afetadas. Para avaliação da severidade, foi utilizada escala diagramática validada por Costa et al. (2018), com adaptações, utilizando-se a mensuração da área foliar atingida por lesões nas folhas. Todos os genótipos se mostraram suscetíveis à bacteriose, sendo 5 considerados moderadamente suscetíveis: $F_{1}$ BRS Pérola do Cerrado x Rosa Intenso, Mar20\#21, Mar20\#15b, Mar20\#24 x Mar20\#40 e FB200PL4R2 x Mar20\#2005, apresentando uma média de severidade que variou de 11 a $25 \%$ de área ou tecidos foliares lesionados.

PALAVRAS-CHAVE: Mancha bacteriana. Xanthomonas axonopodis pv. Passiflorae. Melhoramento genético. Passiflora edulis Sims. Resistência genética. Mudas.

\section{REFERENCES}

BERGAMIN FILHO, A.; AMORIM, L. Manejo de Fitopatossistemas: conceitos básicos. In: BERGAMIN FILHO, A.; AMORIM, L. Doenças de Plantas Tropicais: epidemiologia e controle econômico. Piracicaba: Agronômica Ceres, 1996. p. 189-228.

CAMPBELL, C. L.; MADDEN, L. V. Introduction to plant disease. New York: John Wiley \& Sons, 1990.

CARVALHO, S. L. C.; STENZEL, N. M. C.; AULER, P. A. M. Maracujá-amarelo: Recomendações técnicas para cultivo no Paraná. Londrina: IAPAR, v. Boletim Técnico 83, 2015.

COSTA, A. P. Avaliação de doenças em maracujazeiro azedo: reação de genótipos e validação de escalas diagramáticas. Brasília: Faculdade de Agronomia e Medicina Veterinária, Universidade de Brasília, 2018, 321 páginas. Tese de doutorado. 
COSTA, A. P.; NOGUEIRA, I.; PEIXOTO, J. R.; VILELA, M. D. S.; BLUM, L. E. B.; VENDRAME, W. (2018). Yellow passion fruit reaction to Xanthomonas axonopodis pv. passiflorae and to Cowpea aphid-borne mosaic virus. Crop Breeding and Applied Biotechnology, v. 18, n. 4, 349-356. https://doi.org/10.1590/1984$70332018 \mathrm{v} 18 \mathrm{n} 4 \mathrm{a} 53$

FALEIRO, F. G.; JUNQUEIRA, N. T. V.; COSTA, A. M. Importância socioeconômica e cultural do maracujá. In: FALEIRO, F. G.; JUNQUEIRA, N. T. V. (Eds.) Maracujá: o produtor pergunta, a Embrapa responde. Brasília, DF: Embrapa Cerrados, v. Coleção $\square 500$ Perguntas $\square 500$ Respostas, 2017. p. 15-22.

FALEIRO, F. G.; JUNQUEIRA, N. T. V.; JESUS, O. N. de; COSTA, A. M. Avanços e perspectivas do melhoramento genético de Passifloras no Brasil. In: CONGRESO LATINOAMERICANO DE

PASSIFLORA, 1., 2013, Neiva, Colombia. Libro de Memorias... Neiva: CEPASS HUILA, 2013. p. 12-23.

FERREIRA, D. F. Sisvar: a guide for its bootstrap procedures in multiple comparisons. Ciência e Agrotecnolgia, Lavras, 2014, v. 38, n. 2, p. 109-112. https://doi.org/10.1590/S1413-70542014000200001

FREITAS, J. C. D.; PIO VIANA, A.; SANTOS, E. A.; PAIVA, C. L.; LIMA E SILVA, F. H.; SOUZA, M. M. Sour passion fruit breeding: Strategy applied to individual selection in segregating population of Passiflora resistant to Cowpea aphid-born mosaic virus (CABMV). Scientia Horticulturae, Campos dos Goytacazes, 2016, v. 211, p. 241-247. https://doi.org/10.1016/j.scienta.2016.09.002

FUHRMANN, E.; JUNQUEIRA, N. T. V.; BLUM, L. E. B.; BRAGA, M. W.; BELLON, G.; JUNQUEIRA, K. P. Reação de híbridos interespecíficos de Passiflora spp. à Xanthomonas axonopodis pv. passiflorae. Ciência Rural, Santa Maria, 2014, v. 44, p. 1404-1410. https://doi.org/10.1590/0103-8478cr20121092

GONÇALVES, E. R.; ROSATO, Y. B. Genotypic characterization of xanthomonad strains isolated from passion fruit plants (Passiflora spp.) and their relatedness to different Xanthomonas species. International Journal of Systematic and Evolutionary Microbiology, Campinas, 2000, v. 50, p. 811-821. https://doi.org/10.1099/00207713-50-2-811

IBGE, Instituto Brasileiro de Geografia e Estatística. Desempenho da cultura no Brasil e regiões fisiográficas - Maracujá, 2018. Brasília, DF, 2018. Disponivel em:

$<$ http://www.cnpmf.embrapa.br/Base_de_Dados/index_pdf/dados/brasil/maracuja/b4_maracuja.pdf $>$. Acesso em: 05 jan. 2019.

JUNQUEIRA, N. T. V.; ANJOS, J. R. N.; SILVA, A. P. O.; CHAVES, R. C.; GOMES, A. C. Reação as doenças e produtividade de onze cultivares de maracujá-azedo cultivados sem agrotóxicos. Pesquisa Agropecuária Brasileira, v. 38, n. 8, p. 1005-1010, 2003. https://doi.org/10.1590/S0100-204X2003000800014

KADO, C. I.; HESKETT, M. S. Selective media for isolation of Agrobacterium, Corynebacterium, Erwinia, Pseudômonas and Xanthomonas. Phytopathollogy, , 1970.v. 60, p. 969 - 976. https://doi.org/10.1094/Phyto60-969

LARANJEIRA, F. F. Problemas e perspectivas da avaliação de doenças como suporte ao melhoramento do maracujazeiro. In: FALEIRO, F. G.; JUNQUEIRA, N. T. V.; BRAGA, M. F. (Eds.) MARACUJÁ: germoplasma e melhoramento genético. Planaltina: Embrapa Cerrados, 2005. p. 161-186.

MELETTI, L. M. M.; BERNACCI, L. C.; PASSOS, I. R. D. S. Melhoramento genético do maracujá: passado e futuro. In: FALEIRO, F. G.; JUNQUEIRA, N. T. V.; BRAGA, M. F. (Eds.) MARACUJÁ: germoplasma e melhoramento genético. Planaltina: Embrapa Cerrados, 2005. p. 55-80.

MELETTI, L. M. M. Avanços na cultura do maracujá no Brasil. Revista Brasileira de Fruticultura, Jaboticabal, n. Especial, p. 83-91, 2011. https://doi.org/10.1590/S0100-29452011000500012 
MIRANDA, G. S. Resistência às doenças e qualidade de frutos de genótipos de maracujazeiro azedo, cultivados no Distrito Federal. Brasília: Faculdade de Agronomia e Medicina Veterinária, Universidade de Brasília, 2018, 106 p. Dissertação de Mestrado.

MIRANDA, J. F. Reação de variedades de maracujazeiro-amarelo (Passiflora edulis Sims f. flavicarpa Deg.) a bacteriose causada por Xanthomonas campestris pv. passiflorae. Piracicaba: Escola Superior de Agricultura Luiz de Queiroz / USP, 2004, 62p. Dissertação de Mestrado.

NOGUEIRA, I. Caracterização agronômica e fisíco-química de progênies de maracujazeiro azedo (Passiflora edulis Sims) no Distrito Federal. Universidade de Brasília - Brasília: Faculdade de Agronomia e Medicina Veterinária, 2016. 110 p. Dissertação de Mestrado.

PIO VIANA, A.; GONÇALVES, G. M. Genética quantitativa aplicada ao melhoramento genético do maracujazeiro. In: FALEIRO, F. G.; JUQUEIRA, N. T. V..; BRAGA, M. F. Maracujá: germoplasma e melhoramento genético. Planaltina: Embrapa Cerrados, 2005. p. 243-274.

ROMEIRO, R. S. Métodos em Bacteriologia de Plantas. Viçosa: UFV, 2001.

SANTOS FILHO, H. P.; LARANJEIRA, F. F.; SANTOS, C. C. F. dos; BARBOSA, C. J. Doenças do Maracujazeiro. In: LIMA, A. D. A.; DA CUNHA, M. A. P. (Eds.) Produção e Qualidade na Passiflora. Cruz das Almas: Embrapa Mandioca e Fruticultura, 2004. p. 239-280.

VIANA, F. M. P.; FREIRE, F. das C. O.; CARDOSO, J. E.; VIDAL, J. C. Principais doenças do maracujazeiro na Região Nordeste e seu controle. Fortaleza: Embrapa Agroindústria Tropical, 2003. 7-8 p.

VIANA, C. A. S.; PIRES, M. C.; PEIXOTO, J. R.; JUNQUEIRA, N. T. V.; BLUM, L. E. B. Genotypes of passionfruit to resistance to the bacteriose. Bioscience Journal, v. 30, p. 591 - 598, 2014.

VILELLA, J. G. A. Resistência de cultivares comerciais de maracujazeiro azedo a isolados de Xanthomonas axonopodis pv. passiflorae em condições controladas de casa de vegetação. Brasília: Faculdade de Agronomia e Medicina Veterinária, Universidade de Brasília, 2012, 36 páginas. Monografia. 